\title{
Studies on Biodiversity Diagnosis of Vineyard Farms at the Agro-Ecological Infrastructure Level
}

\author{
Liliana TOMOIAGA ${ }^{1 *}$, Lidia FICIU ${ }^{2}$, Gabriel TABARANU ${ }^{3}$, Cosmina ARGATU ${ }^{4}$, \\ Gabi ZALDEA ${ }^{5}$, Diana VIZITIU ${ }^{6}$ \\ ${ }^{1}$ Research Station for Viticulture and Enology Blaj, Romania \\ ${ }^{2}$ Research Institute for Viticulture and Enology Valea Calugareasca, Romania \\ ${ }^{3}$ Research Station for Viticulture and Enology Bujoru, Romania \\ ${ }^{4}$ Research Station for Viticulture and Enology Murfatlar, Romania \\ ${ }^{5}$ Research Station for Viticulture and Enology Iasi, Romania \\ ${ }^{6}$ Research Institute for Biotechnology in Horticulture Stefanesti, Romania \\ *)Corresponding author, e-mail: tomoiagaliliana@yahoo.com
}

BulletinUASVM Horticulture 73(2) / 2016

Print ISSN 1843-5254, Electronic ISSN 1843-5394

DOI:10.15835/buasvmcn-hort:12306

\begin{abstract}
In Romania, the vine farms are currently spread on approximately 180.000 ha, therefore an important part of biodiversity, functional or planned is present. To avoid a biodiversity decline it is necessary for the vineyards to have a clear evidence of the state of their biodiversity.

This paper presents data on inventory and assessment of the state of biodiversity in agro-ecological infrastructure of vineyards located in the most representative vineyards in Romania. Based on the results obtained from the studied vineyards, during 2015, the agro-ecological infrastructure or AEI percent based on the actual area occupied varies between 7\% and 35\%. Evaluation of the implementation AEI during 2015 in wine-growing farms in Romania showed that the amount of semi-natural elements is not sufficient to stop the biodiversity loss and their quality needs to be maintained.
\end{abstract}

Keywords: agro-ecological infrastructure, biodiversity, diagnosis, viticulture

\section{INTRODUCTION}

In Romania, vine farms are currently spread on approximately 180,000 ha, therefore they constitute an important part of the biodiversity. In order to avoid the biodiversity degradation that is considered an essential factor in maintaining and enhancing the sustainability of the vineyard ecosystem, it is necessary to have a clear image about the current stage of the biodiversity. Although biodiversity conservation is a national objective strategy, until this moment no studies on biodiversity ecosystems diagnosis of vines are extremely low in Romania (Tomoiaga, 2014).

Research conducted in Europe by ecologists: Böller et al. (2004), Daumas (2007), Le Coeur et al. (2002), Helden and Guenser (2009) demonstrate that there is a significant positive correlation between the state of biodiversity of the vineyards' ecosystem and the semi-natural elements of the vine landscape or agro-ecological infrastructure (AEI). Also called ecological compensation area, the agro-ecological infrastructure is represented by stable elements of the vineyard landscape which include: shrubby slopes, hedgerows, alignment trees, isolated trees, grassy areas, ditches, groves, embankments, etc.

\section{MATERIAL AND METHODS}

The paper was developed based on experimental results obtained from the project ADER 3.1.1. titled: "Conservation and management of genetic resources and biodiversity vineyards 


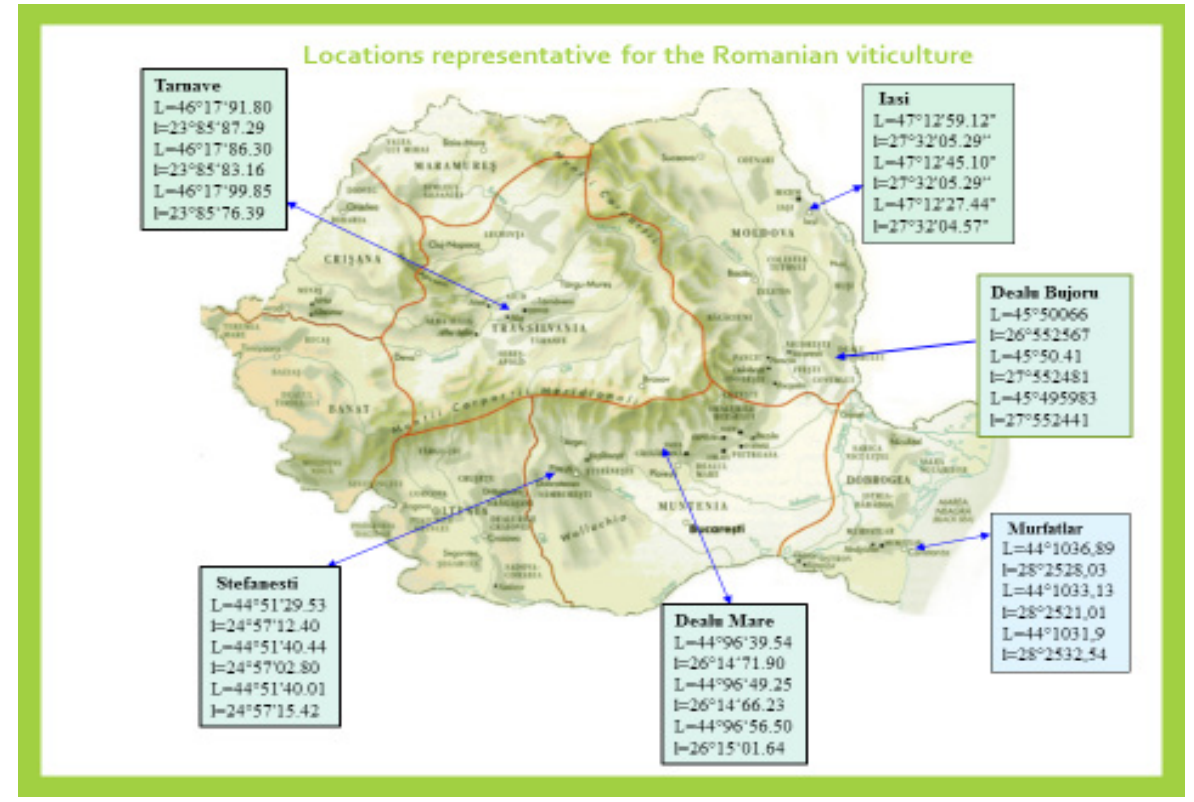

Fig. 1. Experimental plots, 2015

and fruit agro-ecosystem by developing and promoting innovative practices and methods effective eco-friendly environment".

The research was conducted in 2015 in six different representative vineyards for Romanian viticulture as follows: Târnave, Dealul Mare, Dealul Bujoru, Murfatlar, Iaşi Copou and the winegrowing center Ștefănești Argeș.

Biodiversity assessment at the AEI level was carried out in several stages:

- the identification and localization of seminatural elements (AEI), visualization and numbering of management units was carried out on aerial images at a scale of $1 / 2500$;

- identification of species present in the area under review;

- recording the number of individuals of each species;

- determination of the number of species (species richness).

Quantitative assessment of the state of biodiversity was carried out using quantitative indicators measuring the area of semi-natural elements of a farm/parcel setting AEI\% and the artificiality rate or homogeneity of the vineyard landscape.

Qualitative evaluation of the surface structure of the sample AEI was based on an inventory of flora and fauna composition of arthropods supplemented with quantitative information (abundance-dominance).
Flora sampling was conducted in two stages in late May and late September in three sampling locations in a repetitive way: hedges, grass strip, slope, etc.

Samplings of arthropods were taken during July, August and September in three locations in the distance of 50-60 m. All individuals were identified taxonomically using a binocular.

\section{RESULTS AND DISCUSSIONS}

Identification in detail and localization of semi-natural elements or AEI - remains the action of paramount importance to achieve the objectives of conservation and sustainable management of biological diversity. Based on the observations made in experimental fields in conjunction with satellite images the main components of the local matrix/experimental group/area/locality were identified (Fig. 1, 2).

Analysis on the structure and morphology of micro-habitats identified during the vegetation period of 2015 is shown in Tab. 1.

Analyzing the data presented in Tab.1 can be observed that, within each experimental group, the basic vine culture is between $65 \%$ and $93 \%$ of the total vineyard, agro-ecological infrastructure being represented particularly by: hedges, grassy strips with wild flora, natural systems of terraces, rows of trees, isolated trees, slopes, wild flower strips. 


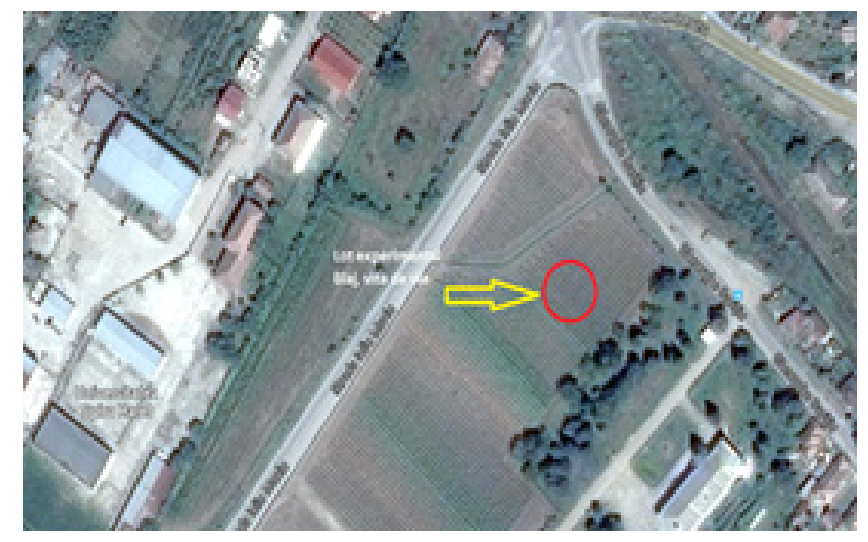

Fig. 2. Landscape matrix (aerial images)

Tab. 1. Viticultural landscape structure at the agro-ecological infrastructure level in the studied area in 2015

\begin{tabular}{|c|c|c|c|c|c|c|c|}
\hline \multirow{2}{*}{$\begin{array}{l}\mathrm{Nr} . \\
\mathrm{crt}\end{array}$} & \multirow{2}{*}{ Specification } & Târnave & Dealu Mare & Bujoru & Murfatlar & Iași & Ștefănești \\
\hline & & ha & ha & ha & ha & ha & ha \\
\hline & Vineyards & 19.20 & 6.45 & 17.10 & 9.72 & 9.88 & 9.77 \\
\hline & Shrubby slopes & 3.60 & 0.42 & 7.00 & 0.22 & 0.39 & 0.41 \\
\hline & Hedge-rows & 2.00 & 0.49 & 0.58 & 0.01 & 0.05 & 0.04 \\
\hline & Tree rows & 0.40 & 0.04 & 0.01 & 0.37 & 0.02 & - \\
\hline & Single trees & 0.12 & 0.14 & 0.01 & 0.26 & 0.02 & 0.02 \\
\hline & Ditches, groves & 0.80 & - & 0.40 & - & 0.14 & - \\
\hline & Grassy areas & 0.72 & - & 1.20 & 0.02 & 0.12 & 0.37 \\
\hline Vines & rd landscape (ha) & 26.84 & 7.54 & 26.30 & 10.60 & 10.62 & 10.60 \\
\hline $\mathrm{Par}$ & el setting AEI \% & 28.46 & 14.46 & 35.00 & 8.30 & 7.00 & 7.83 \\
\hline & ficiality rate $\%$ & 71.54 & 85.54 & 65.00 & 91.70 & 93.00 & 92.17 \\
\hline
\end{tabular}

AEI\% of semi-natural elements in the studied vineyards is variable. Thus AEI percentage is below 10 in the following vineyards: Iași-Copou AEI=7\%. Ștefănești Argeș AEI=7.83\%, and Murfatlar $\mathrm{AEI}=8.30 \%$. Locations with little agro-ecological infrastructures, the AEI is represented by: terraces, hedges, rows of trees, isolated trees and a very high rate of artificiality between $93.6 \%$ and $91.7 \%$. At the opposite, in Bujoru and Târnave vineyards the AEI percentages are high: $\mathrm{AEI}=28.46 \%$ and $\mathrm{AEI}=35 \%$ respectively. In these vineyards the artificiality rates are $71.54 \%$ in Târnave vineyard and $65 \%$ in Dealu Bujoru, reflecting the increasing viticultural heterogeneity favorable for the ecosystem biodiversity conservation.

Flora investigations. In May 2015 were identified 126 species from 30 botanical families. The most representative families were Poaceae (15.8\%), Fabaceae (14.9\%), Asteraceae
(9.2\%), Amarathaceae (8.7\%), Convolvulaceae (7.2\%), Brassicaceae (6.9\%), Polygonaceae (5.2\%), Caryphyllaceae (4.5\%), Lamiaceae (4\%), Umbelliferae (3.1\%), Ranunculaceae (2.8\%), Primulaceae (2.2\%) and Adoxaceae (1.8\%).

In September 70 species of 28 families were determined; the rampant families were: Poaceae (13.2 \%), Asteraceae (11.4\%), Amarathaceae (7.5\%), Lamiaceae $(5.2 \%)$, Convolvulaceae $(5.1 \%)$, Umbelliferae (3.15), Ranunculaceae (1.3\%), Adoxaceae (1.45) - locations with the highest number of species identified. (Tab. 2)

Evaluation of the implementation AEI during 2015 in winegrowing farms in Romania showed that the amount of semi-natural elements is not sufficient to stop the loss of biodiversity and their quality needs to be maintained (Tab. 2, 3).

Arthropod sampling: A total of 3660 individuals were identified of which insects $91.2 \%$ 
Tab. 2. Flora - Mean values of the species (S) 2015

\begin{tabular}{|c|c|c|c|c|c|c|c|}
\hline Location & Month & $\begin{array}{c}\text { Shrubby } \\
\text { slopes }\end{array}$ & $\begin{array}{l}\text { Hedge- } \\
\text { rows }\end{array}$ & $\begin{array}{l}\text { Ditches, } \\
\text { groves }\end{array}$ & Tree rows & Single trees & $\begin{array}{c}\text { Grassy } \\
\text { areas }\end{array}$ \\
\hline \multirow{2}{*}{ Târnave } & May & 15.2 & 11.7 & 7.0 & 14.5 & 10.0 & 15.0 \\
\hline & September & 10.5 & 9.7 & 5.2 & 11.8 & 8.3 & 11.5 \\
\hline \multirow{2}{*}{ Dealu Mare } & May & 12.3 & 8.5 & - & 10.2 & 5.5 & - \\
\hline & September & 7.5 & 6.2 & - & 7.2 & 7.8 & - \\
\hline \multirow{2}{*}{ Dealu Bujoru } & May & 19.5 & 15.5 & 8.7 & 13.8 & 15.2 & 14.5 \\
\hline & September & 11.8 & 13.6 & 7.2 & 9.8 & 6.3 & 10.2 \\
\hline \multirow{2}{*}{ Murfatlar } & May & 9.7 & 10.0 & - & 8.2 & 11.5 & 9.5 \\
\hline & September & 7.2 & 7.3 & - & 6.0 & 6.9 & 8.2 \\
\hline \multirow{2}{*}{ Iași } & May & 11.5 & 5.2 & 5.2 & 7.5 & 8.5 & 8.9 \\
\hline & September & 9.0 & 3.2 & 2.3 & 4.8 & 6.2 & 6.8 \\
\hline \multirow{2}{*}{$\begin{array}{l}\text { Ștefănești } \\
\text { Argeș }\end{array}$} & May & 10.2 & 6.5 & - & - & 6.8 & 8.5 \\
\hline & September & 5.9 & 2.8 & - & - & 4.2 & 7.0 \\
\hline
\end{tabular}

Tab. 3 Fauna - Mean values of species (S) 2015

\begin{tabular}{|c|c|c|c|c|c|c|c|}
\hline Location & Month & $\begin{array}{c}\text { Shrubby } \\
\text { slopes }\end{array}$ & $\begin{array}{l}\text { Hedge- } \\
\text { rows }\end{array}$ & $\begin{array}{l}\text { Ditches } \\
\text { groves }\end{array}$ & $\begin{array}{c}\text { Alignment } \\
\text { trees }\end{array}$ & Single trees & $\begin{array}{c}\text { Grassy } \\
\text { areas }\end{array}$ \\
\hline \multirow{3}{*}{ Târnave } & Iuly & 20.5 & 19.5 & 15.2 & 18.2 & 25.7 & 20.5 \\
\hline & August & 28.9 & 52.6 & 29.5 & 15.5 & 29.5 & 30.5 \\
\hline & September & 35.2 & 38.2 & 30.0 & 20.1 & 36.2 & 30.2 \\
\hline \multirow{3}{*}{ Dealu Mare } & Iuly & 15.2 & 25.2 & - & 15.2 & 19.8 & - \\
\hline & August & 10.8 & 30.5 & - & 10.3 & 23.7 & - \\
\hline & September & 20.5 & 18.6 & - & 20.2 & 20.1 & - \\
\hline \multirow{3}{*}{ Dealu Bujoru } & Iuly & 29.8 & 30.5 & 28.7 & 30.9 & 20.8 & 19.9 \\
\hline & August & 36.2 & 48.6 & 30.1 & 42.5 & 25.9 & 21.9 \\
\hline & September & 30.4 & 28.5 & 28.8 & 35.7 & 28.6 & 20.2 \\
\hline \multirow{3}{*}{ Murfatlar } & Iuly & 19.9 & 21.8 & - & 18.2 & 20.0 & 14.5 \\
\hline & August & 25.2 & 29.4 & - & 19.5 & 21.2 & 17.8 \\
\hline & September & 20.4 & 23.3 & - & 30.2 & 28.4 & 20.2 \\
\hline \multirow{3}{*}{ Iași } & Iuly & 18.8 & 20.4 & 18.2 & 28.3 & 26.5 & 30.3 \\
\hline & August & 15.5 & 30.2 & 15.6 & 20.5 & 30.0 & 26.3 \\
\hline & Septembrie & 20.6 & 32.6 & 30.2 & 19.9 & 31.4 & 22.1 \\
\hline \multirow{3}{*}{$\begin{array}{l}\text { Ștefănești } \\
\text { Argeș }\end{array}$} & Iuly & 15.2 & 35.2 & - & - & 28.4 & 11.8 \\
\hline & August & 20.2 & 25.5 & - & - & 20.7 & 21.3 \\
\hline & September & 21.5 & 18.9 & - & - & 22.2 & 18.9 \\
\hline
\end{tabular}

and Arachnida $8.8 \%$ were collected. Nine order of insects were identified: Coleoptera (21.9\%), Diptera (9.8\%), Homoptera (15.4\%), Thysanoptera (10.7\%), Lepidoptera (7.9\%), Neuroptera (7.1\%) Heteroptera (6.6\%) Orthoptera (6.5\%), Hymenoptera (2.7\%), Aranae (1.4\%). The highest percentage of common species was registered in the case of Coleoptera (21.9\%) and the lowest percentage in the case of Aranae (1.4\%). The highest values of common species were detected at the hedges and buffer strips level.

\section{CONCLUSION}

The percentage of semi-natural elements in the vineyards scenery in Romania is very variable. AEI is below $10 \%$ in: Iași-Copou (AEI 7\%), 
Ștefănești Argeș AEI=7.83\% and Murfatlar with $\mathrm{AEI}=8.3 \%$. At the opposite the Târnave vineyard $\mathrm{AEI}=28.46 \%$ and in Dealu Bujoru AEI $=35.0 \%$.

In the vineyards of: Iași-Copou, Ștefănești Argeș and Murfatlar the artificiality rate is between $93 \%$ and $92.17 \%$. Thus the homogenization of the landscape is very high.

In the Târnave and Dealul Bujoru vineyards the artificiality rate has values below $72 \%$, conditions in which the landscape heterogeneity and biodiversity conservation status is very good.

In the analysis of floristic diversity structure collected at the AEI level, the most representative families were Poaceae (15.8\%), Fabaceae (14.9\%) and Asteraceae (9.2\%). The greatest variability of plant species was reported on the slopes and terraces.

After analyzing the structure of the arthropod fauna at AEI, the highest percentage of dominant species collected belongs to Coleoptera (21.9\%) and the lowest percentage to Aranae (1.4\%). The highest value of species occurrence was detected in hedgerows and buffer strips.

Evaluation of the agro-ecological infrastructure during 2015 in winegrowing farms in Ro- mania showed that the existing semi-natural elements are not enough to maintain biodiversity conservation processes, therefore further interventions has to be made to improve the quality of the current ecosystems.

\section{REFERENCES}

1. Böller EF, Häni F, Poehling HM (Eds) (2004). Ecological infrastructures: Ideabook on functional biodiversity at the farm level. Temperate zones of Europe. Swiss Centre for Agricultural Extension and Rural Development, Switzerland, $212 \mathrm{p}$.

2. Daumas M (2007). Influence du paysage sur les ravageurs de la vigne sur l'appellation Saumur-Champigny. Rapport de Master 2. ENITA de Bordeaux, Université Bordeaux $1,32 \mathrm{pp}$.

3. Le Coeur D, Baudry J, Burel F, Thenail C (2002). Why and how we should study field boundary biodiversity in an agrarian landscape context. Agri. Ecosyst. \& Envt. 89:2340.

4. Tomoiaga L (2014). The Impact of Pesticides on Târnave Vineyard Biodiversity Ecosystem, Bulletin UASVM Horticulture, vol. 72(182).

5. Van Helden M, Guenser J (2009). Conserverez de la biodiversité au Vignoble, techniques de existantes e connaissances actuelles. Revue Oenologues, 133, 14-15. 